\title{
Pulmonary Hypertension in Children with Cancer
}

\author{
Wissam Fakher Oda, Jawad Kadhum Atiya, Assim Alchalabi and Janan G Hasan
}

Department of Pediatrics, Medical College, University of Basra, Iraq

*Corresponding author: Janan G Hasan, Department of Pediatrics, Medical College, University of Basra, Iraq, Tel: 009647801000820; E-mail: jenan_ah03@yahoo.com Received date: November 11, 2016; Accepted date: February 23, 2017; Published date: February 28, 2017

Copyright: (C) 2017 Oda WF, et al. This is an open-access article distributed under the terms of the Creative Commons Attribution License, which permits unrestricted use, distribution, and reproduction in any medium, provided the original author and source are credited.

\author{
Abstract \\ Background: The advances in medicine have led to improved survival rates for children diagnosed with cancer. \\ Despite these improvements, late mortality rates for cancer survivors exceed those of the general population. \\ Leading causes of death in this population include subsequent cancer, followed by pulmonary and cardiovascular \\ events.
}

Objective: To study the frequency of pulmonary hypertension in children with cancer after finishing their treatments, and to study the effects of different determined factors like age of diagnosis or type of treatment on the development of pulmonary hypertension.

Patient and methods: A cross-sectional study was carried out to focus on the frequency of pulmonary hypertension in patients with cancer after finishing their treatment in Basra Children's Specialty Hospital, pediatric oncology center over 6 months; from the 1st of October, 2014 till 31th of March 2015. A total of 67 patients were included in the study, their age ranged from 6 months to 16 years, with 41 males and 26 females. The collected patients have been evaluated for development of pulmonary hypertension by Echocardiograph device in same hospital.

Results: Acute lymphoblastic leukemia accounts for the greatest percentage (34.3\%), followed by Acute myeloid leukemia $(15 \%)$ then Hodgkin`s lymphoma, $(13.4 \%)$ and the rest are solid tumors $(37.3 \%)$. pulmonary hypertension is no statistically significant in relation to type of cancer, $(P=0.729)$. The age of patient at time of diagnoses is statistically significant affects the development of pulmonary hypertension; the frequency tends to occur more in patients who have been diagnosed before the age of five years compared to those diagnosed at age older than 5 years, $(P=0.035)$ but the sex of patient is statistically no significant effect $(P=0.773)$ while no relation to type of treatment with chemotherapy (Methotrexate) radiotherapy is statistically significant $(P=0.04)$. The occurrence of pulmonary hypertension also affected by period after the treatment, cardiovascular complication is more seen in patient who completed two years after finishing treatment with statistically significant association $(P=0.036)$. Pulmonary hypertension occurred more in patients who exposed to radiation for chest, cervical and brain areas (above diaphragm) than those exposed to abdomen (below diaphragm), but statistically no significant $(P=0.264)$. Route of administration of chemotherapy (Methotrexate) either oral or intravenous on the occurrence of pulmonary hypertension is statistically no significant $(P=0.432)$.

Conclusion: The pulmonary hypertension is one of adverse cardiovascular effects that develop in patients who exposed to radiation or certain types of chemotherapy (Methotrexate) so the patient radiotherapy or should have regular screening programs for cardiac functions after complete the course of therapy.

Keywords: Pulmonary hypertension; Children; Cancer

\section{Introduction}

Cancer in children is rare; only about $1 \%$ of new cancer cases [1] in the United States occur among children younger than 19 years of age [2]. Although advances in treatment have increased the overall 5-year survival rate for childhood cancers to approximately $80 \%$, cancer is still the second leading cause of death (following accidents) in children aged 5 to 14 years with slightly increased rates in males and white children [3]. Hematopoietic tumors (leukemia, lymphoma) are the most common childhood cancers, followed by central nervous system (CNS) tumors and sarcomas of soft tissue and bone [2].

The risk of pulmonary conditions is more than three times higher in cancer survivors than in their siblings, as manifested by pulmonary signs (abnormal chest wall growth), symptoms (chronic cough, use of supplemental oxygen, exercise-induced shortness of breath), or specific diagnoses (lung fibrosis, recurrent pneumonia, pleurisy, bronchitis, recurrent sinus infection, or tonsillitis) [4]. Pulmonary fibrosis and pneumonitis are the best-described sequelae of cancer treatment during childhood. However, like most of the late effects of cancer therapy, pulmonary toxicity may first become apparent during the certain chemotherapies, such as bleomycin, can cause lung problems, (pneumonitis and fibrosis). People who get these treatments may have no noticeable symptoms, but for others, problems may start within the first few years after treatment. Diffuse alveolar damage (DAD) is a common pathological manifestation of drug-induced lung injury that results from necrosis of type II pneumocytes and alveolar endothelial cells [5]. Histopathologically, DAD is divided into an acute exudative phase and a late proliferative phase. The exudative phase, which is 
Page 2 of 5

characterized by alveolar and interstitial edema and hyaline membranes, is most prominent in the 1st week after lung injury. The proliferative phase, which is characterized by proliferation of type II pneumocytes and interstitial fibrosis, typically occurs after 1 or 2 wks. Depending on the severity of the injury, fibrosis can improve significantly, remain stable or progress to honeycomb lung. Drugs that most commonly cause (DAD) are bleomycin, busulfan, carmustine, cyclophosphamide, melphalan, methotrexate and mitomycin [6] treatment and persist, or it may not appear until years later [6].

The lungs are particularly sensitive to radiation, and Radiationrelated complications such as pulmonary fibrosis and pneumonitis are most often seen in patients with malignant diseases of the chest, notably HL and solid tumors with pulmonary metastases such as in Wilms tumor and Ewing sarcoma. Asymptomatic abnormal radiographic findings or restrictive changes in pulmonary function testing have been reported in greater than $30 \%$ of patients who received radiation to the lungs. These changes can be detected months to years after completion of therapy, and are most prevalent in individuals with a history of pneumonitis as an acute complication of therapy [6].

\section{Methods}

A cross-sectional study was carried out on children with malignancy (hematological and solid tumor) from the 1st of October, 2014 till 31th of March 2015, who have been finished their treatment at Basrah Children's Specialty Hospital in Pediatric Oncology Center. A total of 67 patients (41 males and 26 females), aged 6 months to 16 years were included in the study.

There are many drugs have tendency to cause pulmonary hypertension, from these, two drugs are available and commonly use in Pediatric Oncology Center in Basrah, which are bleomycin and MTX. The bleomycin was excluded from the study because it use only in treatment of GCT and HL in pediatric age groups and it's pulmonary toxicity is dose-dependent and occurs at treatment doses greater than 400 units [7] and the pediatric dose of bleomycin not reach this dose. The MTX was included in the study because it's tendency to produce lung toxicity is not dose-related [8] and it use in pediatric age groups in treatment of many cancer which include NHL (MTX IV), APL (MTX PO) and ALL (MTX IV and PO). A special data sheet was designed for the purpose of the study (Appendix I). The following information were taken: name, sex, date of birth, past medical history, date of diagnosis, date of starting treatment, date of finishing treatment, date of evaluation, the type of tumor, exposure to radiotherapy, route of chemotherapy (MTX) and Echocardiograph findings. Patients enrolled in the study included patients who finished their treatment course, aged 6 mouths to 16 years, and had adequate information about treatment course. The patients who previously diagnosed with pulmonary hypertension or suffered from the following conditions (which have tendency to cause pulmonary hypertension) were excluded from the study. These conditions included (congenital heart diseases, valvular heart diseases, cardiomyopathies, sickle cell disease or anemia, thalassemia, lung disease, splenectomy, chronic renal failure and thyroid disease.

1. Patients those received methotrexate in their treatment who subdivided into three groups:

a. Patients who exposed to oral Methotrexate

b. Patients who exposed to intravenous Methotrexate c. Patients who exposed to oral and intravenous Methotrexate

2. Patients who received radiotherapy. Those patients were subdivided into two groups:

a. Patients received total body irradiation or to the area above diaphragm.

b. Patients received irradiation to the area below diaphragm.

Because there were deficiency in radiotherapy data for each patient in form of exact cumulative and fractionation doses, so the data was limited for therapeutic doses of irradiation to each type of cancer and for area of exposure as mention above. The diagnosis of pulmonary hypertension was based on examination by Echocardiograph device (PHILIPS, made in Saronno Italy 2003, Model No: MCMD02AA) in same hospital, and the patient considered to have pulmonary hypertension when mean pulmonary arterial pressure more than 25 $\mathrm{mmHg}[9]$.

Statistical analysis was done using Statistical Packages for Social Sciences SPSS program (version 18), data were expressed and comparisons of proportions was performed by crosstab using ChiSquare test when each cell has an expected frequency of five or more and use of Fisher's exact test when each cell has an expected frequency of less than five. The P-value of $<0.05$ was considered statistically significant.

\section{Results}

A total of (67) cases were included in this study, acute lymphoblastic leukemia comprised the highest percentage (34.3\%) compared to other hematological malignancies (AML, APL) which represented (15\%) while Hodgkin lymphoma and Wilm's tumor constituted (13.4\%, 9\%) respectively. The percentage of $(7.5 \%)$ was for each non Hodgkin lymphoma and $\mathrm{NB}$, while $\mathrm{MB}, \mathrm{RB}$, and RMS constituted the lowest percentage among the collected cases $(4.5 \%)$ for each (Table 1 ).

\begin{tabular}{|l|l|l|}
\hline Disease & Number & Percentage \% \\
\hline ALL & 23 & 34.3 \\
\hline AML & 6 & 9 \\
\hline APL & 4 & 6 \\
\hline HL & 9 & 13.4 \\
\hline NHL & 5 & 7.5 \\
\hline Wilms & 6 & 9 \\
\hline NB & 5 & 7.5 \\
\hline RMS & 3 & 4.5 \\
\hline RB & 3 & 4.5 \\
\hline MB & 3 & 4.5 \\
\hline Total & 67 & 100 \\
\hline
\end{tabular}

Table 1: Distribution of cases with pulmonary hypertension according to the type of malignancy.

Table 2 shows that the males more than females cases, $(41,26)$ respectively. In both sex, the largest percentage of cases were among the age group (6-16 years) and it was (75.6\%) for male and (88.5\%) for 
Citation: Wissam Fakher Oda, Jawad Kadhum Atiya, Assim Alchalabi, Janan G Hasan (2017) Pulmonary Hypertension in Children with Cancer. J Carcinog Mutagen 8: 285. doi:10.4172/2157-2518.1000285

Page 3 of 5

female. There is no statistically significant difference concerning the distribution of malignancy in different age groups among male $(\mathrm{P}>0.05)$ and females cases $(\mathrm{P}>0.05)$ (Table 2$)$.

\begin{tabular}{|c|c|c|c|c|c|c|c|c|}
\hline \multirow{4}{*}{$\begin{array}{l}\text { Disea } \\
\text { se }\end{array}$} & \multicolumn{2}{|l|}{ Male } & \multirow{3}{*}{$\begin{array}{l}\text { Total } \\
\begin{array}{l}\text { No. } \\
(\%)\end{array}\end{array}$} & \multirow{3}{*}{$\begin{array}{l}\text { P- } \\
\text { value } \\
6 \mathrm{mo}-5 \\
\mathrm{yr}\end{array}$} & \multicolumn{2}{|l|}{ Female } & \multirow{2}{*}{$\begin{array}{l}\text { Total } \\
\begin{array}{l}\text { No. } \\
(\%)\end{array}\end{array}$} & \multirow{2}{*}{$\begin{array}{l}P \text { - } \\
\text { value }\end{array}$} \\
\hline & \multicolumn{2}{|c|}{$\begin{array}{l}\text { Age of } \\
\text { patients }\end{array}$} & & & \multicolumn{2}{|c|}{$\begin{array}{l}\text { Age of } \\
\text { patients }\end{array}$} & & \\
\hline & $\begin{array}{l}6 \mathrm{mo}-5 \\
\mathrm{yr}\end{array}$ & $6-16 \mathrm{yr}$ & & & $6-16 \mathrm{yr}$ & & & \\
\hline & $\begin{array}{l}\text { No. } \\
(\%)\end{array}$ & $\begin{array}{l}\text { No. } \\
(\%)\end{array}$ & & $\begin{array}{l}\text { No. } \\
(\%)\end{array}$ & $\begin{array}{l}\text { No. } \\
(\%)\end{array}$ & & & \\
\hline ALL & $2(4.9)$ & $\begin{array}{l}13 \\
(31.7)\end{array}$ & $\begin{array}{l}15 \\
(36.6)\end{array}$ & & 0 & $\begin{array}{l}8 \\
(30.8)\end{array}$ & $\begin{array}{l}8 \\
(30.8)\end{array}$ & \\
\hline AML & $1(2.4)$ & $3(7.3)$ & $4(9.8)$ & & $1(3.8)$ & $1(3.8)$ & $2(7.7)$ & \\
\hline APL & 0 & $2(4.9)$ & $2(4.9)$ & & 0 & $2(7.7)$ & $2(7.7)$ & \\
\hline $\mathrm{HL}$ & $1(2.4)$ & $\begin{array}{l}5 \\
(12.2)\end{array}$ & $\begin{array}{l}6 \\
(14.6)\end{array}$ & & 0 & $\begin{array}{l}3 \\
(11.5)\end{array}$ & $\begin{array}{l}3 \\
(11.5)\end{array}$ & \\
\hline $\mathrm{NHL}$ & $2(4.9)$ & $2(4.9)$ & $4(9.8)$ & 0.392 & 0 & $1(3.8)$ & $1(3.8)$ & 0.369 \\
\hline Wilms & 0 & $1(2.4)$ & $1(2.4)$ & & $2(7.7)$ & $\begin{array}{l}3 \\
(11.5)\end{array}$ & $\begin{array}{l}5 \\
(19.2)\end{array}$ & \\
\hline NB & $2(4.9)$ & $1(2.4)$ & $3(7.3)$ & & 0 & $2(7.7)$ & $2(7.7)$ & \\
\hline RMS & 0 & $2(4.9)$ & $2(4.9)$ & & 0 & $1(3.8)$ & $1(3.8)$ & \\
\hline RB & $1(2.4)$ & $1(2.4)$ & $2(4.9)$ & & 0 & $1(3.8)$ & $1(3.8)$ & \\
\hline MB & $1(2.4)$ & $1(2.4)$ & $2(4.9)$ & & 0 & $1(3.8)$ & $1(3.8)$ & \\
\hline
\end{tabular}

Table 2: Distribution of cases with malignancies in relation to sex and age of patients.

Table 3 shows that the $\mathrm{PH}$ were detected in (9\%) of 67 estimated cases. The distribution of the (9\%) of $\mathrm{PH}$ were as the following; (3\%) for each ALL and HL and (1.5\%) for each APL and Wilm's tumor. There is no statistically significant difference concerning the distribution of $\mathrm{PH}$ cases regarding the type of malignancy (Table 3).

\begin{tabular}{|c|c|c|c|c|}
\hline Disease & PH No. (\%) & $\begin{array}{l}\text { No PH No. } \\
(\%)\end{array}$ & Total No. (\%) & P-value \\
\hline AML & 0 & $6(9)$ & $6(9)$ & \\
\hline APL & $1(1.5)$ & $3(4.5)$ & $4(6)$ & \\
\hline $\mathrm{HL}$ & 2 (3) & $7(10.4)$ & $9(13.4)$ & \\
\hline $\mathrm{NHL}$ & 0 & $5(7.5)$ & $5(7.5)$ & \\
\hline Wimls & $1(1.5)$ & $5(7.5)$ & $6(9)$ & \\
\hline NB & 0 & $5(7.5)$ & $5(7.5)$ & \\
\hline RMS & 0 & $3(4.5)$ & $3(4.5)$ & \\
\hline RB & 0 & $3(4.5)$ & $3(4.5)$ & \\
\hline
\end{tabular}

\begin{tabular}{|l|l|l|l|l|}
\hline MB & 0 & $3(4.5)$ & $3(4.5)$ & \\
\hline Total & $6(9)$ & $61(91)$ & $67(100)$ & \\
\hline
\end{tabular}

Table 3: Distribution of cases with pulmonary hypertension according to type of malignancy.

Table 4 shows the distribution of $\mathrm{PH}$ according to the age of diagnosis where $(7.5 \%)$ of cases had $\mathrm{PH}$ in younger age groups (6 months- 5 years) and (1.5\%) of cases had $\mathrm{PH}$ in older age groups (6-16 years). There is statistically significant difference concerning the distribution of $\mathrm{PH}$ cases in relation to age of diagnosis. The table shows that there is no statistically significant difference in regarding to sex of patients (Table 4).

\begin{tabular}{|l|l|l|l|l|}
\hline \multirow{2}{*}{ Variables } & \multicolumn{2}{|l|}{ PH } & $\begin{array}{l}\text { Total No. } \\
(\%)\end{array}$ & \multirow{2}{*}{ P-value } \\
\cline { 2 - 4 } & Yes No. (\%) & No No. (\%) & $\begin{array}{l}\text { Age of } \\
\text { Diagnosis }\end{array}$ & \\
\hline 6 mo-5 years & $5(7.5)$ & $22(32.8)$ & $27(40.3)$ & \\
\hline $6-16$ years & $1(1.5)$ & $39(58.2)$ & $40(59.7)$ & \multirow{2}{*}{0.035} \\
\hline Total & $6(9)$ & $61(91)$ & $67(100)$ & \\
\hline Sex & & & & \\
\hline Male & $4(6)$ & $37(55.2)$ & $41(61.2)$ & \\
\hline Female & $2(3)$ & $24(35.8)$ & $26(38.8)$ & \multirow{2}{*}{0.773} \\
\hline Total & $6(9)$ & $61(91)$ & $67(100)$ & \\
\hline
\end{tabular}

Table 4: Distribution of cases with pulmonary hypertension according to age of diagnosis and sex.

Table 5 shows the distribution of $\mathrm{PH}$ among patients who received MTX. The percentage of PH was (9\%), (4.5\%) appeared among patients who received MTX and the rest (4.5\%) among those not received it with no statistically significant difference. The percentage of $\mathrm{PH}$ in patients who received radiotherapy was $(6 \%)$ while the $(3 \%)$ represented the cases with $\mathrm{PH}$ that were not treated by radiotherapy. There is statistically significant difference concerning the distribution of $\mathrm{PH}$ cases in relation to radiotherapy (Table 5).

\begin{tabular}{|c|c|c|c|c|}
\hline \multirow{2}{*}{$\begin{array}{l}\text { Type } \\
\text { treatment }\end{array}$} & \multicolumn{2}{|l|}{ PH } & \multirow{2}{*}{$\begin{array}{l}\begin{array}{l}\text { Total No. } \\
(\%)\end{array} \\
\text { MTX }\end{array}$} & \multirow{2}{*}{ P-value } \\
\hline & $\begin{array}{ll}\begin{array}{l}\text { Yes } \\
(\%)\end{array} & \text { No. }\end{array}$ & No No. (\%) & & \\
\hline Yes & $3(4.5)$ & $29(43.3)$ & $32(47.8)$ & \multirow{3}{*}{0.908} \\
\hline No & $3(4.5)$ & $32(47.8)$ & $35(52.2)$ & \\
\hline Total & $6(9)$ & $61(01)$ & $67(100)$ & \\
\hline \multicolumn{5}{|l|}{ Radiation } \\
\hline Yes & $4(6)$ & $14(20.9)$ & $18(26.9)$ & \multirow{2}{*}{0.04} \\
\hline No & $2(3)$ & $47(70.1)$ & 49 (73.1) & \\
\hline
\end{tabular}


Page 4 of 5

\begin{tabular}{|l|l|l|l|l|}
\hline Total & $6(9)$ & $61(91)$ & $67(100)$ & \\
\hline
\end{tabular}

Table 5: Distribution of cases with pulmonary hypertension according to type of treatment.

Table 6 shows the distribution of $\mathrm{PH}$ according to post treatment duration where all six cases (9\%) that diagnosed with $\mathrm{PH}$ appeared in patients who had post treatment duration more than two years. There is statistically significant difference concerning the distribution of $\mathrm{PH}$ cases in relation to post treatment duration. The table also shows the distribution of $\mathrm{PH}$ in relation to the duration of oral MTX where (3.7\%) represented the PH among patients treated with MTX for 12 months while $(7.4 \%)$ was the percentage of $\mathrm{PH}$ in patients who received MTX for 30 months without statistically significant difference (Table 6).

\begin{tabular}{|c|c|c|c|c|}
\hline \multirow{2}{*}{ Variables } & \multicolumn{2}{|l|}{ PH } & \multirow{2}{*}{$\begin{array}{l}\begin{array}{l}\text { Total } \\
(\%)\end{array} \\
\begin{array}{l}\text { Post } \\
\text { treatment } \\
\text { duration }\end{array}\end{array}$} & \multirow{2}{*}{ P-value } \\
\hline & Yes No. (\%) & No No. (\%) & & \\
\hline$\leq 2 \mathrm{yr}$ & 0 & $28(41.8)$ & $28(41.8)$ & \multirow{3}{*}{0.036} \\
\hline$>2 \mathrm{yr}$ & $6(9)$ & $33(49.3)$ & 39 (58.2) & \\
\hline Total & $6(9)$ & 61 (91) & $67(100)$ & \\
\hline \multicolumn{5}{|c|}{$\begin{array}{l}\text { Duration of oral } \\
\text { MTX }\end{array}$} \\
\hline 12 mouths & $1(3.7)$ & $3(11.1)$ & $4(14.8)$ & \multirow{4}{*}{0.393} \\
\hline 18 mouths & 0 & $8(29.6)$ & $8(29.6)$ & \\
\hline 30 mouths & $2(7.4)$ & $13(48.1)$ & $15(55.6)$ & \\
\hline Total & $3(11.1)$ & 24 (88.9) & $27(100)$ & \\
\hline
\end{tabular}

Table 6: Distribution of cases with pulmonary hypertension according to post treatment duration and duration of oral MTX.

Table 7 shows the distribution of $\mathrm{PH}$ among patients received radiotherapy above and below diaphragm where the largest percentage of $\mathrm{PH}$ appeared among patient who received radiotherapy above diaphragm (15\%). There is no statistically significant difference concerning the distribution of $\mathrm{PH}$ cases in relation to area of exposure to radiotherapy. The table also shows the distribution of $\mathrm{PH}$ in patients received same chemotherapy (MTX) by different routes; MTX IV (15.6\%), MTX PO (12.5\%), and mixed both routes $(71.9 \%)$ where (3.1\%) of PH appeared in patients with PO MTX, (6.3\%) represented the PH among patients who received MTX by both routes (PO, IV). There is no statistically significant difference concerning the distribution of PH cases in relation to route of MTX administration (Table 7).

\begin{tabular}{|l|l|l|l|l|}
\hline \multirow{2}{*}{$\begin{array}{l}\text { Type } \\
\text { treatment }\end{array}$} & \multicolumn{2}{|l|}{ PH } & $\begin{array}{l}\text { Total No. } \\
\text { (\%) }\end{array}$ & \multirow{2}{*}{ P-value } \\
\cline { 2 - 4 } & $\begin{array}{l}\text { Yes No. } \\
\text { (\%) }\end{array}$ & No No. (\%) & $\begin{array}{l}\text { Radiation } \\
\text { area }\end{array}$ & \\
\hline Above diaphragm & $3(15)$ & $7(35)$ & $10(50)$ & \multirow{2}{*}{0.264} \\
\hline Below diaphragm & $1(5)$ & $9(45)$ & $10(50)$ & \\
\hline
\end{tabular}

\begin{tabular}{|l|l|l|l|l|}
\hline Total & $4(20)$ & $16(80)$ & $20(100)$ & \\
\hline MTX route & & & & \\
\cline { 1 - 4 } MTX IV & 0 & $5(15.6)$ & $5(15.6)$ & \\
\cline { 1 - 4 } MTX PO & $1(3.1)$ & $3(9.4)$ & $4(12.5)$ & \multirow{2}{*}{0.432} \\
\cline { 1 - 4 } Both & $2(6.3)$ & $21(65.6)$ & $23(71.9)$ & \\
\hline Total & $3(9.4)$ & $29(90.6)$ & $32(100)$ & \\
\hline
\end{tabular}

Table 7: Distribution of cases with pulmonary hypertension according to different exposure area for radiotherapy and different route of administration for MTX.

\section{Discussion}

It is important to remember that only in 50 years ago the ability to diagnose and manage childhood cancer was rudimentary \& survival was less than $10 \%$, today more than $70 \%$ of children diagnosed with cancer survive and the majority is considered cured [10]. Despite that, the late adverse effects of treatment modalities should be considered during and after treatment courses. The pulmonary hypertension is one of adverse cardiovascular effects that develop in patients who exposed to radiation or certain types of chemotherapy (MTX).

The study shows that the percentage of $\mathrm{PH}$ among cases is (9\%) which consider a high percentage regarding the occurrence of $\mathrm{PH}$ in general population and this findings similar to the results of study carried out by Mertens et al. [4] that shown the risk of pulmonary conditions was more than three times higher in cancer survivors than in their siblings. The study shows that there is no relation between the type of malignancy and development of $\mathrm{PH},(\mathrm{P}=0.729)$ which is statistically not significant. This finding is correlated with the fact that the lung metastasis and malignancies, which can cause interstitial lung disease and subsequently lead to $\mathrm{PH}$, are rare in childhood [11].

In relation to age of diagnosis, the study deal with all pediatric age groups that can theatrically complete the shortest course of cancer therapy which is 6 months like treatment of $\mathrm{RB}, \mathrm{MB}$ and Wilm's tumor. The age of diagnosis was divided into two groups; one of them includes infant, toddlers and preschool age group (6 months -5 years old) and the other involves school age group and adolescents (6-16 years). The study found out statistically significant association between the younger age group and the risk of $\mathrm{PH}(\mathrm{P}=0.035)$. This finding is similar to study displayed by Lopez et al. [12] and other research was done by Miller et al. [13]. The well-defined relation between the radiation and younger age group is because the radiation for malignancy results in pulmonary fibrosis with loss of lung volume as in adult and older children, in addition to compromise the pulmonary function by inhibited growth of the supportive structures and the chest wall in younger children [14]. The study also shows that the development of $\mathrm{PH}$ among male and female cases have no statistically significant association between sex and $\mathrm{PH}(\mathrm{P}=0.773)$. This finding corresponds to result of other study carried out by Rubin [15], which revealed that the development of $\mathrm{PH}$ not affected by gender of patient during childhood.

In case of MTX, the toxicity is dose independent, but differs by change the route of administration. The study shows no statistically significant association between the treatment by MTX and development of $\mathrm{PH},(\mathrm{P}=0.908)$. This result was properly due to the rarity of $\mathrm{PH}$ cases caused by MTX (incidence below 1\%) [8] and due to 
Page 5 of 5

a small numbers of patients who received these treatment. For the same reason of the small sample size, the development of $\mathrm{PH}$ reveals no statistically significant difference in patients received MTX by different ways of administration $(\mathrm{P}=0.432)$, but the difference in the percentage was similar to study carried out by Cottin et al. [16] who shown the relation between the oral low dose MTX and development of lung toxicity.

Regarding the cases who received radiotherapy in their treatment course, the development of $\mathrm{PH}$ appears more common among patients got radiation compared to that patients not received it. This finding reveals statistically significant association between exposure to radiotherapy and development of $\mathrm{PH},(\mathrm{P}=0.04)$. This result correlates with research was done by Weiner et al. [17] and other study carried out by Mertens et al. [4], who shown statistically significant associations were present for lung fibrosis and chest radiation $(\mathrm{P}=0.001)$.

The study also estimates the relation between the $\mathrm{PH}$ and the location of exposed area to radiation and finds that the occurrence of $\mathrm{PH}$ appears more among the patients exposed to radiation above diaphragm. Despite these obvious differences, the association is not statistically significant. The difference in the percentage of $\mathrm{PH}$ cases between two groups (above and below diaphragm) corresponds to results of others research was done by Liles et al. [18], which revealed that rick of lung injury increases proportionally with lung volume exposed to radiation, but the non-significant P-value may due to small size sample who received radiotherapy in this study.

The study considers two age groups depend on the period after completing treatment course, the first group with post treatment duration (2 years or less) and the second group with (more than 2 years). All the six cases which diagnosis with $\mathrm{PH}$ appear in patients who have more than 2 years post treatment duration with statistically significant association, $(\mathrm{P}=0.036)$. This finding is similar to study carried out by Rosiello et al. [19], which displayed that the time of clinical manifestations of pulmonary toxicity induced by anticancer therapy may delay up to two years after treatment completed. This explained by the histo-pathological phases that take place in lung when it exposed to chemotherapy. These phases included the exudative phase, which is most prominent in the 1st week after lung injury and the reparative phase, which typically occurs after 1 or 2 wks. Depending on the severity of the injury, fibrosis can improve significantly, remain stable, or progress to honeycomb lung [6]. Same things occur in radiotherapy, in which the patients may develop progressive pulmonary fibrosis, usually 6 to 24 months after treatment [20].

\section{Conclusion}

The study compared the duration of oral MTX among three groups of patients; APL with oral MTX for 12 mouths, ALL in female with oral MTX for 18 mouths and ALL in male with oral MTX for 30 mouths. The results shown no statistically significant association between the duration of oral MTX and development of $\mathrm{PH},(\mathrm{P}=0.393)$. This results were similar to other study carried out by Rossi et al., which shown that there is no correlation between the development of drug toxicity and the duration of MTX or its total cumulative dose [21].

\section{References}

1. Dietz AC, Chen Y, Yasui Y, Ness KK, Hagood JS, et al. (2016) Risk and impact of pulmonary complications in survivors of childhood cancer: A report from the Childhood Cancer Survivor Study. Cancer 122: 36873696.

2. McLean T, Wofford M (2015) Oncology. In: Marcdante K, Kliegman R (eds). Nelson essentials of pediatrics; 7th ed. Philadelphia, Saunders, an imprint of Elsevier Inc 534-552.

3. Ward E, DeSantis C, Robbins A, Kohler B, Jemal A (2014) Childhood and adolescent cancer statistics, 2014. CA: A Cancer Journal for Clinicians 64: 83-103.

4. Mertens A, Yasui Y, Liu Y (2002) Pulmonary complications in survivors of childhood and adolescent cancer. A report from the Childhood Cancer Survivor Study. Cancer 95: 2431-2441.

5. Kay J (1996) Drug-induced lung disease. In: Hasleton PS, (ed). Spencer's pathology of the lung; 5th ed. New York, NY: McGraw-Hill 551-595.

6. Armenian S, Meadows A, Bhatia S (2011) Late effects of childhood cancer and its treatment. In: Pizzo P, Poplack D (eds). Principles and Practice of Pediatric Oncology, 6th Ed. Philadelphia, Pa: Lippincott, Williams, \& Wilkins 1368-1387.

7. O'Sullivan J, Huddart R, Norman A (2003) Predicting the risk of bleomycin lung toxicity in patients with germ-cell tumours. Ann Oncol 14: $91-96$.

8. Lateef O, Shakoor N, Balk R (2005) Methotrexate pulmonary toxicity. Expert Opin Drug Saf 4: 723-730.

9. Idrees M, Saleemi S, Azem M, Aldammas S, Alhazmi M, et al. (2014) Saudi guidelines on the diagnosis and treatment of pulmonary hypertension: 2014 updates. Ann Thorac Med 9: 1-15.

10. MargolinJ, Rabin K, Steuber C, Poplack D (2011) Acute Lymphoblastic Leukemia. In: Pizzo P, Poplack D (eds). Principles and Practice of Pediatric Oncology, 6th Ed.Philadelphia, Pa: Lippincott, Williams, \& Wilkins 427-443.

11. Simonneau G, Gatzoulis M, Adatia I (2013) Updated clinical classification of pulmonary hypertension. J Am Coll Cardiol 62: 34-41.

12. López JA, Compte L, Ferrís J, Domenech R, Pérez S, et al. (1999) Risk factors for lung toxicity in pediatric cancer survivors. An Esp Pediatr 51: 505-511.

13. Miller R, Fusner J, Fink R, Murphy T, Getson P, et al. (1986) Pulmonary function abnormalities in long-term survivors of childhood cancer. Med Pediatr Oncol 14: 202-207.

14. Wiebe E, Rodrigues G (2006) Radiation-induced Lung injury. Oncol Exchange J 5: 29-35.

15. Rubin LJ (2006) Primary pulmonary hypertension. Proc Am Thorac Soc J 3: 111-115.

16. Cottin V, Tebob J, Massonnet B (1996) Pulmonary function in patients receiving long-term methotrexate. Chest 109: 933-938.

17. Weiner D, Maity A, Carlson C (2006) Pulmonary function abnormalities in children treated with whole lung irradiation. Pediatr Blood Cancer 46: 222-227.

18. Liles A, Blatt J, Morris D, Sharma A, Goldsby R, et al. (2008) Monitoring pulmonary complications in long-term childhood cancer survivors. Cleveland Clin J Med 75: 531-539.

19. Rosiello R, Merrill W (1990) Radiation-induced lung injury. Clin Chest Med 11: 65-71.

20. Carver J, Shapiro C, Virgo K, Jacobs L, Schwartz C, et al. (2007) American Society of Clinical Oncology Clinical Evidence Review on the Ongoing Care of Adult Cancer Survivors: Cardiac and Pulmonary Late Effects. J Clin Oncol 25: 3991-4007.

21. Rossi S, Erasmus J, McAdams H, Sporn T, Goodman P (2000) Pulmonary Drug Toxicity: Radiologic and Pathologic Manifestations. Radio Soci North Am J 20: 1245-1259. 